\title{
Isolation and characterization of diesel oil degrading indigenous microrganisms in Kwazulu-Natal, South Africa
}

\author{
C. Singh and J. Lin* \\ School of Biochemistry, Genetics, Microbiology and Plant Pathology, University of KwaZulu-Natal (Westville), Private \\ Bag X 54001, Durban, Republic of South Africa. \\ Accepted 5 December, 2007
}

\begin{abstract}
Uncontrolled releases of petroleum compounds that are carcinogenic, mutagenic and are potent immunotoxicants into soil and groundwater poses a serious threat to human and animal health. Biodegradation of hydrocarbon-contaminated soils has been established as an efficient, economic, versatile and environmentally sound treatment. Ten indigenous microorganisms were isolated from contaminated soils using the enrichment technique. Five isolates with the highest degradation potentials under standard degradation conditions were identified as Acinetobacter calcoaceticus (LT $_{1}$ and $\left.\mathrm{ETS}_{2}\right)$, Acinetobacter sp. ( $\left.\mathrm{LT}_{1} \mathrm{~A}\right)$, Citrobacter freundii $\left(\mathrm{MRC}_{3}\right)$ and Bacillus pumilus $\left(\mathrm{JL}_{\mathrm{B}}\right)$. B. pumilus achieved $86.94 \%$ of diesel degradation in 2 weeks. Additional degradation assay was carried out in liquid media using 3 local commercial fertilizers as nutrient supplements in comparison with the Bushnell-Haas (BH) media. The results show that the addition of fertilizer F1 stimulated diesel degradation by all isolates especially $B$. pumilus while the addition of fertilizer F3 seemed to strongly inhibit the bacterial ability of diesel degradation. The inoculation with the consortia did not show a higher degradation potential than the individual isolate. The results strongly indicate that environmental conditions of the contaminated sites play a crucial role in the degradation even though additional diesel-degrader has been introduced into the contaminated site.
\end{abstract}

Key words: Diesel bioremediation, Bacillus sp, Acinetobacter calcoaceticus sp., Citrobacter freundii.

\section{INTRODUCTION}

Petroleum continues to be used as the principle source of energy; however, despite its important usage, petroleum hydrocarbons also pose as a globally environmental pollutant (Plohl et al., 2002). South Africa is especially vulnerable to oil spills due to the high volume of oil transported around the coasts. Protective and preventive measures need to be taken into account to avoid spillage into the environment. Spillages of oil have become a common occurrence in recent history. In 1983, a major spill of 250,000 tons of oil occurred in South Africa by the tanker known as Castillo De Belluer. In 2000, two large oil spillages near and in Cape Town threatened the South

${ }^{\star}$ Corresponding author. E-mail: linj@ukzn.ac.za. Tel: +27-312607407. Fax: +27-31-2607809.
African penguin population and damaged major tourist attraction sites such as Robben Island (Avian Demography Unit, 2000). In 2002, another oil-spillage occurred near $12 \mathrm{~km}$ South of the St. Lucia estuary. The cargo was still being removed in 2004 (Department of Environmental Affairs and Tourism, 2004) and the estuary house was only reopened in 2006 to avoid ecological disaster demonstrating how time-consuming a clean-up operation can be. Oil spills in coastal areas cause immediate and obvious problems to animals and plants. There are also long-term effects on ecosystems related to the release of toxic components over a prolonged period as the oil breaks up and the concentration of toxicants in organisms towards the top of the food chain increases (Samanta et al., 2002).

Petroleum contamination also results from leakage above ground and underground storage tanks, spillage 
during transport of petroleum products, abandoned manufactured gasoline sites, other unplanned releases and current industrial processes (Mishra et al., 2001; Sarkar et al., 2005). Uncontrolled releases of these compounds into soil and ground water are frequent as a result of accidents or poor control practices and attract public interest (Mishra et al., 2001; Roling et al., 2002; Atlas and Philp, 2005). Petroleum compounds are considered to be recalcitrant to microbial degradation and persist in ecosystems because of their hydrophobic nature and low volatility and thus they pose a significant threat to the environment (Abed et al., 2002). The constituents of these contaminants such as diesel oil, are carcinogenic, mutagenic and are potent immunotoxicants, thus posing a serious threat to human and animal health (Boonchan et al., 2000; Samanta et al., 2002). Oil spills, especially in soil contamination have prompted research on cost-effective, environmentally benign cleanup strategies (Margesin and Schinner, 2001).

Biodegradation of hydrocarbon-contaminated soils, which exploits the ability of microorganisms to degrade and/or detoxify organic contaminants, has been established as an efficient, economic, versatile and environmentally sound treatment (Mehrashi et al., 2003). Since hydrocarbons are natural products, it is not surprising to find organisms that are able to degrade these energy-rich substrates (Delille et al., 2002). The ability of microbes to degrade organic contaminants into harmless constituents has been explored as a means to biologically treat contaminated environments. It is the subject of many research investigations and real-world applications and it is the basis for the emergent field of bioremediation (Atlas and Philp, 2005).

This report deals with the isolation of diesel-degrading bacteria and determination of the biodegradation potentials of the pure cultures of selected bacterial isolates as well as consortia.

\section{MATERIALS AND METHODS}

\section{Collections of diesel contaminated soil samples}

Eight diesel-contaminated soil samples were collected from six different transport companies in and around Durban, South Africa. $100 \mathrm{~g}$ of each sample was placed into $500 \mathrm{ml}$ Schott bottles and stored at $4^{\circ} \mathrm{C}$ until further study. The diesel was purchased from a local garage and stored in the dark at ambient temperature throughout the study.

\section{Isolation of bacterial diesel degraders}

Bushnell - Haas (BH) medium (Atlas, 1994) was used as the enrichment media with $10 \%(\mathrm{v} / \mathrm{v})$ diesel as the sole carbon source to isolate diesel-degrading bacteria. $10 \mathrm{~g}$ of the contaminated soil was added and incubated at $30^{\circ} \mathrm{C}$ at $170 \mathrm{rpm}$. After 2 weeks, $1 \mathrm{ml}$ of enriched media was transferred into freshly prepared enrichment media and incubated at the same conditions as described above. Serial dilutions $(1 / 10)$ from the third enrichment process were plated out onto $\mathrm{BH}$ agar plates, which were covered with $100 \mu \mathrm{l}$ of diesel oil and incubated at $30^{\circ} \mathrm{C}$. The single colonies were streaked onto nutrient agar plates, incubated at $30^{\circ} \mathrm{C}$ overnight, and stored at $4^{\circ} \mathrm{C}$ until further use.

The oil-degrading isolates were identified by gram stain, biochemical tests (Balows et al., 1992) and confirmed by 16S rDNA sequencing (Marchesi et al., 1998). For long-term preservation, the bacterial isolates were stored in $40 \%$ glycerol at $-70^{\circ} \mathrm{C}$.

\section{Characterization of the degradation potential}

The preliminary biodegradation assays were performed as described by Mandri and Lin (2007) with modifications. A single colony of the isolate was inoculated into $10 \mathrm{ml}$ nutrient broth (Merck) at $30^{\circ} \mathrm{C}$ overnight. The overnight culture was centrifuged for $15 \mathrm{~min}$ at 3500 rpm. The cell pellet was washed twice and was re-suspended with $\mathrm{BH}$ medium until $\mathrm{OD}_{600}$ was equivalent to 1.2 .

One $\mathrm{ml}$ of bacterial inoculum (1.2 $\mathrm{OD}_{600}$ equivalent) was transferred into $100 \mathrm{ml} \mathrm{BH}$ medium with $5 \mathrm{ml}(5 \%)$ diesel and was incubated at $30^{\circ} \mathrm{C}$ at $170 \mathrm{rpm}$ for two weeks. A control devoid of the bacterial isolate was prepared for each set of experiments. All experiments were performed in duplicate.

The biodegradation assays were also performed using selected isolates and using local commercial fertilizers as nutrient supplements instead of $\mathrm{BH}$ media under the same conditions.

The growth patterns were obtained by measuring the optical density at $600 \mathrm{~nm}$ and total viable counts (cfu/ml) of the isolates were determined by the spread plate technique after the incubation of the nutrient agar plates at $30^{\circ} \mathrm{C}$ for $24 \mathrm{~h}$.

\section{Determination of diesel degradation}

The level of diesel oil degradation was determined using the gravimetric analysis (Chang, 1998; Marquez- Rocha et al., 2001). The percentage of diesel remaining was calculated compared to the control.

\section{RESULTS}

The preliminary biodegradation assay was carried out to determine the diesel degradation capabilities of the 10 indigenous microbial cultures that were isolated from contaminated environments. Preliminary investigation of these cultures in $\mathrm{BH}$ media together with agitation and aeration for 2 weeks allowed microbial degradation of the diesel oil as shown in (Figure 1). The isolate $\mathrm{JL}_{B}$ accelerated a high degradation of $86.94 \%$, whereas isolate $\mathrm{SC}_{1}$ showed the least degradation of $1.484 \%$. The 5 best diesel-degraders could also degrade diesel up to $60.3 \%$ under stationary conditions (Data not shown). These 5 isolates were identified as $A$. calcoaceticus $\left(\mathrm{LT}_{1}\right.$ and $\left.\mathrm{ETS}_{2}\right)$, Acinetobacter sp. $\left(\mathrm{LT}_{1} \mathrm{~A}\right), \mathrm{C}$. freundii $\left(\mathrm{MRC}_{3}\right)$ and Bacillus pumilus $\left(\mathrm{JL}_{\mathrm{B}}\right)$. A. calcoaceticus $\left(\mathrm{LT}_{1}\right)$, Acinetobacter sp. $\left(\mathrm{ETS}_{2}\right)$ and $B$. pumilus $\left(\mathrm{JL}_{\mathrm{B}}\right)$ with highest degradation potentials were used for the following study.

Additional degradation assay was carried out in liquid media using 3 local commercial fertilizers as nutrient supplements in comparison with the $\mathrm{BH}$ media. The results in Figure 2 demonstrate the degradation rates of different combinations of bacterial isolates and the nutrients under the same conditions as described above 


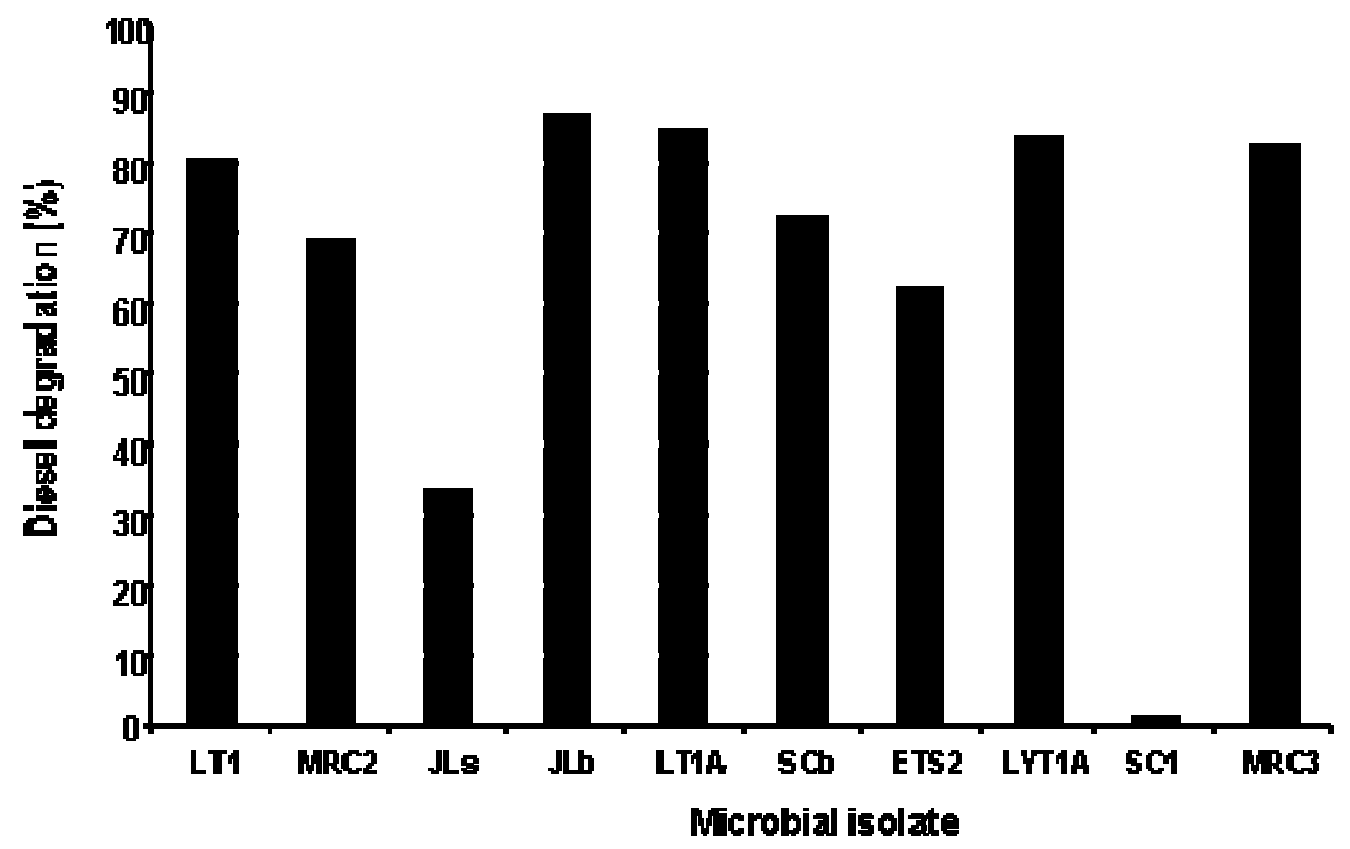

Figure 1. Percentage of diesel degradation by bacterial isolates under the standard degradation conditions. $\mathrm{LT}_{1}$ and $\mathrm{ETS}_{2}$ : Acinetobacter calcoaceticus; $\mathrm{LT}_{1} \mathrm{~A}$ : Acinetobacter sp.; $\mathrm{MRC}_{3}$ : Citrobacter freundii; and $\mathrm{JL}_{\mathrm{B}}$ : Bacillus pumilus. The remaining five isolates were unidentified Gramnegative bacteria.

after 2 weeks. The combination of $A$. calcoaceticus $\left(\mathrm{ETS}_{2}\right)$ and fertilizer $\mathrm{F} 1$ exhibited a highest degradation of $90.28 \%$. The addition of fertilizer F1 stimulated the diesel degradation of the isolates especially $B$. pumilus (from 53- $81 \%$ ), while the addition of fertilizer F3 seemed to strongly inhibit the bacterial ability of diesel degradation. The fertilizer F2 was the less enhancer than F1 (Data not shown). The results in Figure 2 also show that the bacterial consortia of all three isolates did not improve the level of diesel degradation than the individual isolate under the same conditions.

\section{DISCUSSION}

Microorganisms are extremely diverse and can adapt to survive in inhospitable environments. Microbes are capable of breaking down many complex molecules by adaptation of their degradative enzyme system (Sohal and Srivastava, 1994). Microorganisms play important roles in the natural environment; they contribute to the geological cycle of elements and transformation of natural chemicals (Watanabe, 2002). Contaminated sites often harbour a vast array of microbial flora that is capable of utilizing the contaminant as an energy and carbon source (Watanabe, 2002; Das and Mukherjee, 2006).

The contaminated soil samples were enriched and subsequently 10 bacterial isolates were subcultured. The preliminary assay showed that eight of the ten isolates possess the diesel degradation potentials. B. pumilus isolate $\left(\mathrm{JL}_{\mathrm{B}}\right)$ seemed to have the best degradation of $86.94 \%$. Several Acinetobacter isolates were also found with the diesel degradation potentials. All isolates in this study have been commonly reported as hydrocarbondegraders in various environments (da Cunha et al., 2006; Ilori et al., 2006; Mihial et al., 2006, Kim and Crowley, 2007).

Few studies (Annweiller et al., 2000; ljah and Antai, 2003; Sorkhoh et al., 1993) have reported on the roles of Bacillus spp. in hydrocarbon bioremediation; although there are several reports of bioremediation of pollutants by the action of Bacillus spp. occurring in extreme environments. Ijah and Antai (2003) reported Bacillus spp. as being the predominant isolate of all the crude oil utilizing bacteria characterized from highly polluted soil samples (30 and $40 \%$ crude oil). It was postulated that Bacillus spp. are more tolerant to high levels of hydrocarbons in soil due to their resistant endospores. There is growing evidence that isolates belonging to the Bacillus sp. could be effective in clearing oil spills (Ghazali et al., 2004).

Acinetobacter species was the most frequent isolate in this study as reported in the literature as the most common bacterial hydrocarbon-degraders (Rusansky et al., 1987; Kiyohara et al., 1992; Johnson et al., 1996; Barathi and Vasudevan, 2001; Bhattacharya et al., 2002; Pokethitiyook et al., 2003; Van Hamme et al., 2003). Acinetobacter spp. are widespread in nature and can remove or degrade a wide range of organic and inorganic 


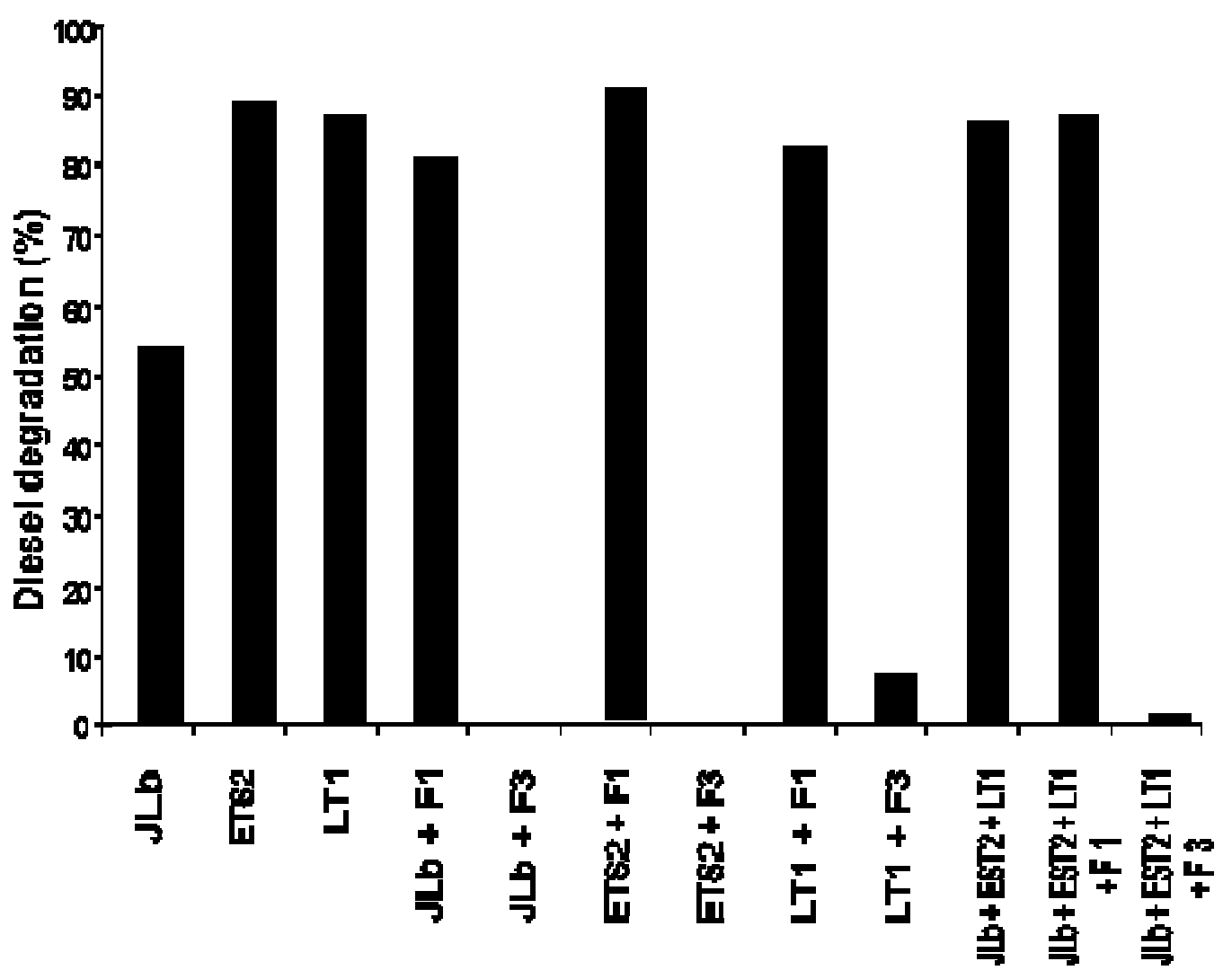

Figure 2. Percentage of diesel degradation by bacterial isolates using commercial fertilizers ( $F 1$ and $\mathrm{F} 3$ ) as nutrient comparison with $\mathrm{BH}$ media under the same degradation conditions. $\mathrm{JL}_{\mathrm{B}}$ : Bacillus pumilus isolate; $\mathrm{LT}_{1}$ : Acinetobacter calcoaceticus isolate; $\mathrm{ETS}_{2}$ : Acinetobacter sp.

compounds (Auling et al., 1991; Wagner et al., 1994; Boswell et al., 2001; Briganti et al., 1997; Zilli et al., 2001; Abdel-El-Haleem et al., 2002). Acinetobacter species have shown the potentials in both environmental and biotechnological applications (Abdel-El-Haleem 2003). Another A. calcoaceticus isolate was also obtained in this laboratory and was found to degrade used engine oil (Mandri and Lin, 2007).

Biodegradation of complex hydrocarbons in nature usually requires the cooperation of more than a single species. Microbial populations that consist of strains that belong to various genera have been detected in petroleum-contaminated soil (da Cunha et al., 2006; Ilori et al., 2006; Mihial et al., 2006, Kim and Crowley, 2007). This strongly suggests that each strain or genera have their roles in the hydrocarbon transformation processes (Ghazali et al., 2004; Cunliffe and Kertesz, 2006). Individual microorganisms can metabolize only a limited range of hydrocarbon substrates, so assemblages of mixed populations with overall broad enzymatic capacities are required to bring the rate and extent of petroleum biodegradation further. However, in this study, inoculation with the consortia did not show a higher degradation potential (Figure 2). All isolates obtained in this study were isolated through the same enrichment process; therefore the best diesel degraders obtained might possess the similar abilities and occupy the same niches. The inoculated isolates might compete for the same carbon source and the consortia might not be able to perform better than the individual isolate. In addition, the differences in the cell number, that the cell mass of the inoculants with the pure isolate was higher than that of the same isolate in the consortia, probably also contribute to the observation. Inoculation has been shown to be efficient when the contaminants belong to a single type of recalcitrant compound (Thomassin-Lacroix et al., 2002).

In order to explore the potential of in situ bioremediation of indigenous isolates, the local commercial fertilizers were randomly selected as alternative nutrient sources instead of $\mathrm{BH}$ media. The addition of different commercial fertilizers caused a significant difference in the ability of diesel degraders to break down diesel. The fertilizer F1 stimulated the diesel degradation abilities of all isolates. $B$. pumilus $\left(\mathrm{JL}_{\mathrm{B}}\right)$ was found to be the best diesel-degrader in the presence of fertilizer F1. However, the addition of fertilizer F3 inhibited dramatically the degradation abilities of same isolates. Walworth et al. (1997) reported the enhancement and inhibition of soil 
petroleum biodegradation through the use of fertilizer nitrogen.

Some researchers have reported that inoculation had positive, marginal or no effects on oil biodegradation rates (Margesin and Schinner, 1997; Venosa et al., 1992). Microorganisms that possess the degradative ability of organic pollutants in cultures may fail to function when inoculated into the natural environment. Using different fertilizers as the nutrient sources had a significant impact on diesel degradation of the same isolate. The results strongly indicate that the environmental conditions including physical and chemical conditions of the contaminated sites play a crucial role in the degradation even though additional diesel-degrader has been introduced into the contaminated site. It might be feasible to harbour microorganisms from a contaminated site, because the microbes have adapted to a contaminated environment and utilizes the contaminant as a carbon and energy source (Sohal and Srivastava, 1994; Watanabe, 2002; Ghazali et al., 2004; Das and Mukherjee, 2006).

Bioremediation has been widely received by the public. However, a number of factors must be taken into consideration before in situ bioremediation can be applied. These include (i) type and concentration of oil contaminated; (ii) prevalent climatic conditions; (iii) type of environment that has been contaminated; and (iv) nutrient content as well as $\mathrm{pH}$ of the contaminated site (Rosenberg, 1992). Further research will be directed towards understanding the roles of individual isolate in influencing the effectiveness of a microbial association as well as the optimal degradation conditions in situ.

\section{ACKNOWLEDGEMENTS}

This project was financially supported by the National Research Foundation (GUN 2069344) and the University Competitive Research Grant, University of KwaZuluNatal, South Africa.

\section{REFERENCES}

Abdel-El-Haleem D (2003). Acinetobacter: environmental and biotechnological applications. Afr. J. Biotechnol. 2(4): 71-74.

Abdel-El-Haleem D, Moawad H, Zaki E, Zaki S (2002) Molecular characterization of phenol-degrading bacteria isolated from different Egyptian ecosystems. Microb. Ecol. 43: 217-224.

Abed MMR, Safi NMD, Koster J, deBeer D, El-Nahhal Y, Rullkotter J, Garcia-Pichel F (2002). Microbial diversity of a heavily polluted microbial mat and its community changes following degradation of petroleum compounds. Appl. Environ. Microbiol. 68(4): 1674-1683.

Annweiller E, Richnow HH, Antranikian G, Hebenbrock S, Garms C, Franke S, Francke W, Michaelis W (2000). Naphthalene degradation and incorporation of naphthalene-derived carbon into biomass by the thermophile Bacillus thermoleovorans. Appl. Environ. Microbiol. 66: 518-523.

Atlas RM (1994). Handbook of Biological media, Parks Ed. CRC Press, p. 175

Atlas RM, Philp J (2005). Bioremediation: applied microbial solutions for real-world environmental cleanup. ASM Press, Washington, D.C., pp. 1-292.
Auling G, Pilz F, Busse HJ, Karrasch S, Streichan M, Schon G (1991). Analysis pf the polyphosphate-accumulating microflora in phosphorus-eliminating, anaerobic-aerobic activated sludge systems by using diaminopropane as a biomarker for rapid estimation of Acinetobacter spp. Appl. Environ. Microbiol. 57: 3585-3592.

Avian Demography Unit (2000). Department of Statistical Sciences. University of Cape Town. Press Release: Rescue of seabirds in Western Cape. [Online.] http://web.uct.ac.za.

Balows A, Truper HG, Dworkin M, Harder W, Schleifer KH (1992). The Prokaryotes: A handbook on the biology of bacteria. Springer Verlag, Heidelberg, Germany.

Barathi S, Vasudevan N (2001). Utilization of petroleum hydrocarbons by Pseudomonas fluorescens isolated from a petroleumcontaminated soil. Environ. Int. 26: 413-416.

Bhattacharya D, Sarma PM, Krishnan S, Mishra S, Lal B (2002). Evaluation of genetic diversity among Pseudomonas citronellolis strains isolated from oily sludge-contaminated sites. Appl. Environ. Microbiol. 69(3): 1435-1441.

Boonchan S, Britz ML, Stanley GA (2000). Degradation and mineralisation of high-molecular weight polycyclic aromatic hydrocarbons by defined fungal-bacterial cocultures. Appl. Environ. Microbiol. 66(3): 10.

Boswell CD, Dick RE, Essles H, Macaskie LE (2001). Phosphate uptake and release by Acinetobacter johnsonli in continuous culture and coupling of phosphate release to heavy metal accumulation. J. Ind. Microbiol. Biotechnol. 26: 333-340.

Briganti F, Pessione E, Giunta C, Scozzafava A (1997). Purification, biochemical properties and substrate specificity of a catechol 1,2 dioxygenase from a phenol degrading Acinetobacter radioresistens. FEBS Lett. 416: 61-64.

Chang R (1998). Chemistry ( $6^{\text {th }}$ edition), McGraw-Hill Companies, Inc. 24: $962-963$.

Cunliffe M, Kertesz MA (2006). Effect of Sphingobium yanoikuyae B1 inoculation on bacterial community dynamics and polycyclic aromatic hydrocarbon degradation in aged and freshly $\mathrm{PAH}$-contaminated soils. Environ. Pollut., pp. 1-10.

da Cunha CD, Rosado AS, Sebastián GV, Seldin L, von der Weid I (2006). Oil biodegradation by Bacillus strains isolated from the rock of an oil reservoir located in a deep-water production basin in Brazil, Appl. Microbiol. Biotechnol. 73(4): 949-959.

Das K, Mukherjee AK (2006) Crude petroleum-oil biodegradation efficiency of Bacillus subtilis and Pseudomonas aeruginosa strains isolated from a petroleum-oil contaminated soil from North-East India. Bioresour. Technol., pp. 1-7.

Delille D, Delille B, Pelletier E (2002). Effectiveness of bioremediation of crude oil contaminated Subantarctic Intertidal Sediment: the microbial response. Microb. Ecol. 44: 118-126.

Department of Environmental Affairs and Tourism (2004). Ministry of Environmental Affairs and Tourism. [Online.] http://www.environment.gov.za.

Ghazali FM, Rahman RNZA, Salleh AB, Basri M (2004). Biodegradation of hydrocarbons in soil by microbial consortium. Int. Biodeterior. Biodegradation 54: 61-67.

ljah UJJ, Antai SP (2003). Removal of Nigerian light crude oil in soi over a 12-month period. Int. Biodeterior. Biodegradation. 51: 93-99.

Ilori MO, Oladipupo AO, John EC, Sarah O, Adekunle AS (2006). Occurrence and growth potentials of hydrocarbon degrading bacteria on the phylloplane of some tropical plants. Afri. J. Biotechnol. 5(7): 542-545.

Johnson K, Anderson S, Jacobson CS (1996) Phenotypic and genotypic characterization of phenanthrene-degrading fluorescent Pseudomonas biovars. Appl. Environ. Microbiol. 62: 3818-3825.

Kim J-S, Crowley DE (2007). Microbial Diversity in Natural Asphalts of the Rancho La Brea Tar Pits, Appl. Environ. Microbiol. published online ahead of print on 6 April 2007.

Kiyohara H, Takizawa N, Nagao K (1992). Natural distribution of bacteria metabolizing many kinds of polyaromatic hydrocarbons. J. Ferment. Bioeng. 74: 49-51.

Mandri T, Lin J (2007). Isolation and Characterization of Engine Oil Degrading Indigenous Microorganisms in KwaZulu-Natal, South Africa, Afr. J. Biotechnol. 6(1): 23-27.

Marchesi J, Sato RT, Martin AJ, Hiam SJ, Wade W (1998). Design and 
evaluation of bacterium-specific PCR primers that amplify genes coding for bacterial 16S rRNA. Appl. Environ. Microbiol. 64(2): 795799.

Margesin R, Schinner F (1997). Efficiency of indigenous and inoculated cold-adapted soil microorganisms for biodegradation of diesel oil in Alpine soils. Appl. Environ. Microbiol. 63(7): 2660-2664.

Margesin R, Schinner F (2001). Bioremediation (natural attentuation and biostimulation) of diesel-oil contaminated soil in an Alpine glacier skiing area. Appl. Environ. Microbiol. 67(7): 3127-3133.

Marquez-Rocha FJ, Hernandez-Rodriguez V, Lamela MT (2001) Biodegradation of diesel oil in soil by a microbial consortium. Water, Air Soil Pollut. 128: 313-320.

Mehrashi MR, Haghighi B, Shariat M, Naseri S, Naddafi K (2003). Biodegradation of petroleum hydrocarbons in soil. Iranian J. Public Health. 32(3): 28-32.

Mihial DJ, Thiruvenkatachari Viraraghavan F, Jin Y-C (2006). Bioremediation of Petroleum-Contaminated Soil Using Composting, Pract. Periodical Hazard. Toxic Radioactive Waste Manage., 10(2): 108-115.

Mishra S, Jyot J, Kuhad RC, Lal B (2001). Evaluation of inoculum addition to stimulate in situ bioremediation of oily-sludgecontaminated soil. Appl. Environ. Microbiol. 67(4): 1675-1681.

Plohl K, Leskovsek H, Bricelj M (2002). Biological degradation of motor oil in water. Acta Chim. Slovenica. 49: 279-289.

Pokethitiyook P, Sungpetch A, Upathame S, Kruatrachue M (2003). Enhancement of Acinetobacter calcoaceticus in biodegradation of Tapis crude oil. Appl. Environ. Microbiol. 42: 1-10.

Roling WFM, Milner MG, Jones DM, Lee K, Daniel F, Swannell RJP, Head IM (2002). Robust hydrocarbon degradation and dynamics of bacterial communities during nutrient-enhanced oil spill bioremediation. Appl. Environ. Microbiol. 68 (11): 5537-5548.

Rosenberg $E$ (1992). The hydrocarbon-oxidizing bacteria. p. 446-459. In Balows A, Truper HG, Dworkin M, Harder W, Schleifer KH (ed.) The prokaryotes: a handbook on the biology of bacteria: ecophysiology, isolation, identification, applications. Springer Verlag, Heidelberg, Germany.

Rusansky S, Avigad R, Michaeli S, Gutnick DL (1987). Involvement of a plasmid in growth on and dispersion of crude oil by Acinetobacter calcoaceticus RA57. Appl. Environ. Microbiol. 53: 1918-1923.

Samanta KS, Singh OV, Jain RK (2002). Polycyclic aromatic hydrocarbons: environmental pollution and bioremediation. Trends Biotechnol., 20(6): 243-248.

Sarkar D, Ferguson M, Datta R, Birnbaum S (2005). Bioremediation of petroleum hydrocarbons in contaminated soils: Comparison of biosolids addition, carbon supplementation, and monitored natural attenuation. Environ. Pollut. 136: 187-195.
Sohal SH, Srivastava AK (1994). Environment and Biotechnology. Role of biotechnology in pollution control. Ashish Publishing House. New Dehli., pp. 163-170.

Sorkhoh NA, Ibrahim AS, Ghannoum MA, Radwan SS (1993). High temperature hydrocarbon degradation by Bacillus stearothermophilus from oil-polluted Kuwait desert. Appl. Microbiol. Biotechnol., 39: 123126.

Thomassin-Lacroix EJM, Eriksson M, Reimer KJ, Mohn WW (2002) Biostimulation and bioaugmentation for on-site treatment of weathered diesel fuel in Artic soil. Appl. Microbiol. Biotechnol. 59: 551-556.

Van Hamme JD, Singh A, Ward OP (2003). Recent advances in petroleum microbiology. Microbiol. Mol. Biol. Rev. 67(4): 503-549.

Venosa AD, Haines JR, Allen DM (1992). Efficacy of commercial inocula in enhancing biodegradation of weathered crude oil contaminating a Prince William Sound beach. J. Ind. Microbiol. 10: 111.

Wagner M, Erhart R, Manz W, Amann R, Lemmer H, Weidi D, Schleifer $\mathrm{KH}$ (1994). Development of an rRNA-targeted oligonucleotide probe specific for genus Acinetobacter and its application for in situ monitoring in activated sludge. Appl. Environ. Microbiol. 56: 3125 3129.

Walworth JL, Woolard CR, Braddock JF, Reynolds CM (1997). Enhancement and inhibition of soil petroleum biodegradation through the use of fertilizer nitrogen: an approach to determining optimum levels. J. Soil Contam. 6(5): 465-480.

Watanabe K (2002). Linking genetics, physiology and ecology: an interdisciplinary approach for advancing bioremediation. J. Biosci. Bioeng. 94(6): 557-562.

Zilli M, Palazzi E, Sene L, Converti A, Borghi MD (2001). Toluene and stryene removal from air in biofilters. Process Biochem. 10: 423-429. 